\title{
Bioscientists in Greece: To Be Or Not To Be A Teacher?
}

\author{
Katerina Kedraka (Corresponding author) \\ Assistant Professor, Democritus University of Thrace, Greece \\ Email: kkedraka@mbg.duth.gr
}

Katerina Linara

Graduate of Molecular Biology \& Genetics, Democritus University of Thrace

Email: katelinalin@gmail.com

Eleni Anna Mandala

Graduate of Molecular Biology \& Genetics, Democritus University of Thrace

Email: elenmand2@mbg.duth.gr

Received: July 22, 2016 Accepted: August 09, 2016 Published: August 19, 2016

doi:10.5296/ijhrs.v6i3.9915 URL: http://dx.doi.org/10.5296/ijhrs.v6i3.9915

\begin{abstract}
Career development is a significant part of a person's life. For Bioscientists in Greece finding a job is not easy, especially recently, due to a severe economic crisis the country goes through, which has negatively affected the labor market. Although their academic curricula during their graduate studies strongly urge them towards research, most of them make a living as teachers in high schools. This study is a quality research on Bioscientists's career in Education in Greece. Data was collected through interviews and the sample includes 16 Greek Bioscientists -seven working in Education and nine in other areas. For the results, Content Analysis was used and it revealed that for those working in a high school, although it wasn't always their first choice, it turned out to be a good job alternative. For those who didn't choose Secondary Education to work in, Academia is considered as an excellent career option but the limitation of available positions makes them turn to other employment alternatives, like pharmaceutical companies or marketing. To conclude, Bioscientists' career in Greece seems to be a dynamic process, formed according to personal interests, values and one's personality as well as to external, mainly economic, factors, leading them to realistic, personal pursuits.
\end{abstract}

Keywords: Education, Career, Decision making, Bioscientists, Quality research 


\section{Introduction}

Career is defined as a persons' lifelong process regarding his work orientation, as well as the decision on his actual profession or business he wishes or seeks (Kantas \& Chatzi, 1991). According to career developmental theories of Ginzberg and Super, a person goes through a series of phases and completes his career development by stabilizing his job preferences and his final job selection. According to Ginzberg et. al (1951) the phases a person goes through, are: 1) the phase of imagination (during childhood), 2) the pilot phase (11-18 years) and 3) the realistic phase (18-24 years). In the realistic phase, when the actual career direction takes place, there are three more sub-phases: a) investigation, b) crystallization and c) determination. In the sub-phase of investigation, various opportunities and alternative solutions are investigated, but at this point the range of options, have been narrowed and the person focuses only on a few basic interests. In the next two sub-phases, the final synthesis of the forces exercised on a person to make his decisions, takes place. Also, during these sub-phases one makes his final decision about a specific work area which has already been determined by a previous decision (e.g. freelance, public or private sector, research etc). Through later modifications in Ginzberg's theory (1957), despite the critical role of decisions which have been underlined concerning the years of early maturity, work path derives from a lifetime decision process and it does not necessarily result in compromise. The alternative term that is suggested is 'optimization', which indicates a persons' effort for the best possible combination of reality and personal pursuits.

Super (1953) argues that the whole process of career choice and adjustment can be summed up in a series of life stages or major cycles, which are: (1) the growth stage, (2) the exploration stage, (3) the establishment stage, (4) the maintenance stage and (5) the decline stage. The exploration stage is subdivided into the fantasy stage, the trial stage and the realistic stage. The establishment stage is subdivided into the trial and the stability stages. According to Super, the process of career development is a constant, ongoing process of development and realization of our self- perception. To be more specific, it is a compromise (or synthesis) process between individual and social factors, between the self- perception and the real world. Finally, work satisfaction derives not only from a single vocational choice, but from life itself, since it is directly related to the individual's realization of self- perception, e.g, if one has managed to find the best way to express his abilities, interests, personality features and values. In 1984 Super argued that each individual's career model is determined by his personal features (such as interests, mental abilities, sex, personality features), family's socioeconomic status and the overall economical situation and the actual opportunities at the time of career decision.

In addition, many educational and motivational psychological theories on vocational choice focus on the role of intrapersonal and interpersonal factors on career decision making. Bandura in his Social Learning theory $(1977,1995)$ emphasizes the feeling of self-efficacy. The higher the assessment of self-efficacy is, the vaster is the range of career perspectives that people seek. Krumboltz (1979) also highlights the role of social learning in the formulation of value judgments concerning the individual himself and the world, which affect career decision making. These value judgments, that Krumboltz called self-observant 
generalizations, are referred to: (1) someone's adequacy to complete a project, that is, if he disposes the proper skills to carry out the project, (2) his interests and (3) his personal values. All these self-judgments, the direct and indirect support one gets from his family and the positive or negative feedback one gets from his environment about a specific career, can affect his decision.

In order to fully comprehend the vocational choice, it is also useful to take into consideration Eccles' theory (1983) on the of Expectancy of Value. According to this theory, people believing that their task has value (it is important and interesting) for them, try harder and give it more time and chances. Thus, according to Eccles (2009) the success and value expectancies on different tasks or professions, directly affect their choices on studies and future career.

In Greece, Bioscientists' absorption in the labor market is considered 'difficult'. According to the latest research of the Horizontal Support Action of the Universities' Career Offices in 2008, data concerning the employment of the graduates of Biosciences' Departments shows that the rate of employed Biologists, 5-7 years after their graduation, is $64.6 \%$, while the rate of registered unemployed Biologists is $5.8 \%$ and of inactive graduates is $29.6 \%$ (but $67.1 \%$ of graduates are considered inactive due to their ongoing postgraduate studies). It's worth saying that the employment rate of Biology graduates is the $4^{\text {th }}$ lowest among all the graduates of other scientific fields. It is interesting, though, that Biologists who have a stable and permanent job, seem satisfied with it (72.6\%). Moreover, Biology graduates, compared to all graduates, have a very high employment rate in the public sector, but this rate is much lower in self-employment and their income is generally similar to the average income in Greece.

But where can a Bioscientist find a job? As Sciences expand and modern research methods require synergy and collaboration, workplaces related to Biosciences and their applications are continuously increasing (Brown, 2007). The area that absorbs several Bioscientists is research, both in public sector (e.g. universities, research centers, ecology etc) and in profit organizations (e.g. pharmaceutical, agricultural companies etc) (Belikoff, 2004). Environmental and ecology issues, like the climate change or the conservation of species in danger on the planet, provide a promising field for Bioscientists, who are considered as the most appropriate trained scientists to deal with these issues (Bloomfield \& El-Fakahany, 2008). Finally, world interest in Science seems to be increased. This interest has led to an increase in printed and on-line publications. As a result, young Bioscientists can work in this area (Ambrose, 2006; Longman, 2006). Biotechnology, Biomedicine and the growing needs for prevention and diagnostic methods, mainly related to Genetics and Molecular Biology, is a broad, modern area for Bioscientists (Roth, 2006). Education, traditionally, offers many jobs with good employment prospects for Bioscientists at the level of Secondary Education. Working as an academic, on the other hand, is still considered as the most appealing career choice among specialized Bioscientists, since they often have a $\mathrm{PhD}$, because it provides the chance for running scientific research and teaching at the same time (Robbins-Roth, 2006). Recently, an increasing demand for Bioscientists as adult-educators in non-traditional educational grounds has evolved. For example, dealing with the environment and ecology 
has gathered the attention of many people, mostly volunteers, who need to be trained in basic biology terms and methods. Furthermore, many high-level specifications and applications in the medical field have created a need for training several scientific or professional groups (e.g. doctors, technicians) in the modern methods and techniques of Biosciences (Camenson,1993).

In Greece, work fields related to research, diagnostics, biomedicine, genetics, biotechnology etc, do not offer a lot of available positions, so Bioscientists often work in Education, either as teachers in High Schools in the public or the private sector, or as private tutors preparing students for their final exams for higher education, whereas a small number work in Academia, where there are not enough positions for everyone holding a PhD (Kedraka, 2013).

\section{Research Methodology}

The purpose of this research is to investigate the variety of the careers' paths of Bioscientists in Greece. The research question was why they chose (or not) a career in Education. The methodology follows the qualitative approach which is considered as the most appropriate in cases the aim of the research is a thorough understanding of thoughts and experiences of the interviewees (Kyriazi, 1998). In our study data was collected through 16 interviews from Bioscentists and the open questions and the dialogue were the means to detect their personal choices, views and experiences. This empirical research took place from June to December 2014 and anonymous interviews were conducted to seven (7) Biology teachers who work in public High Schools in Greece and nine (9) Bioscientists who work in different areas. Thus, data comes from a sample of sixteen (16) Bioscientists: seven Biology High School teachers and two pharmaceutical company's (marketing and medical affairs) executives, one employee in an administrative position of a public organization, one employee in biotope-wetland, one academic, one employee in the Ministry of Development, one serviceman in Greek police, one employee in Natural History Museum and one employee in a public hospital.

Interviews allowed the researchers to have a deeper understanding of the personal philosophy of each Bioscientist, since the interviewees can choose to reveal whatever they consider important -in other words, their own truth (Kedraka, 2008). Through face to face communication the purpose and the overall framework of this research became clear to everyone, so that the research methodology ensured privacy, responsibility and validity of data collection and management (Kyriazi, 1998). It is worth mentioning that the participants were very open and willing to disclose their opinion and experiences. A tape recorder was used to record interviews (with the permission of the interviewees), and oral data was transferred to a written text. This text was consequently processed through the method of Content Analysis, which is considered as the most appropriate method for "decoding and interpreting written data and especially personal beliefs, attitudes, assumptions and perspectives" (Verma \& Mallick, 2004: 224). Finally, qualitative interpretation and assessment of the answers took place. 


\section{Macrothink}

\section{Results}

Content analysis revealed that regarding the careers of the Bioscientists being asked, they are divided into two basic subcategories: a) those who chose Education as a career and b) those who built careers in other sectors.

\subsection{Bioscientists who work as high school teachers}

Bioscientists who work as high school teachers state that even if Education wasn't their initial career choice, they are working in it due to economic needs, indicating the safety of working in the public sector as the most important reason for their choice:

"I was finally appointed to public Education, after 13 years that I had been working as a private tutor ... but I can't say that I had a permanent and secure job... as time went by, family requirements led me to public Education".

"Education makes you feel secure, it allows you to live in a way that you couldn't do otherwise".

"I come from a poor family; we were farmers, to be a teacher it was a really big deal".

Some others Biologists - school teachers seemed to compromise due to difficult vocational rehabilitation in other Biology fields:

"No, it wasn't my best choice to work in Education, I was interested in other fields like research, but I didn't manage to find a proper job on that".

"I preferred to work as a Biologist and not as a teacher, as a researcher, in life sciences, even now, I would prefer to have a career as a researcher..., but this dream didn't come true, now maybe, I have idealized it".

"Education, when I was appointed, was the easy way to be employed, because appointment in public schools was relatively easy or it was going to start soon. I felt that industry, biotechnology or other fields of Biology needed more effort in order to have a career in them, and this was something I didn't have the clear mind to do at that time".

Some, though, actually tried to build a different career besides Education, but finally, after several years of job experience and poor job satisfaction, they ended up as teachers:

"I had worked as a pre-service teacher for 9 months, then I was employed as ichthyologist ... and I worked there for 2 years. Then an appointment in the Ministry of Education came up and I chose to work as a high school teacher".

"When I was studying Biology I wasn't thinking of being a teacher, I wanted to be a researcher. But having worked in laboratories, I can say that being a teacher is such a nice job, because we have to deal with youngsters ... they are life-giving. Thinking it back, I would never change it".

\subsection{Bioscientists who didn't choose Education as a career}

There are some interesting answers coming from those who didn't choose Education as a 
career. Some of them were sure that this was the right thing to do, since Education was not in their preferences:

"I think that I would be bored if I were a teacher, Education was going to devour me, it is a profession that is interesting up to a point, I worked on it for 7 years, I really had enough".

"For me it wasn't my best choices, I would have thought Education only if I hadn't managed to find another job. Personally, I like laboratory”.

"No, Education wasn't something that appealed to me. You might say...I had never thought about it".

Some think Education is not the right choice, due to both demanding studies they have completed and to the "no-enticing" option of working in the public sector:

"Since I was in University I had said no to Education. I didn't want to, not because I didn't like Education but I considered Biology as something that couldn't be limited to Secondary Education. Teaching is something different than Biology-it is not science!".

"I didn't permit myself to think about working in Education after so demanding studies, I had not even thought about it, the work conditions there were not for me".

"When I graduated as a Biologist, there was a priority list of Biologists who wanted to work in public schools. At that time I actually applied to be in this list. Then this list was abolished and I had to take competitive exams -and I didn't! After all these studies (Master, PhD, working in public research laboratory), I thought it was such a pity to waist them for being a teacher, ... I must be incredibly crazy to take exams in order to be a teacher".

"I decided that me and the public sector had nothing in common. The public sector was just not for me. I tried to find a job in the private sector'.

Nevertheless, there are some among those who didn't choose a career in Education even though they consider it as a good vocational choice:

"To be honest, I would like to work in Education. I consider the people who work there lucky. I would have a different career now. My mother is still telling me: 'you are stupid that you didn't become a teacher' (laughs)'”.

"Of course, (Education) is a vocational choice that lots of Biologists follow. I worked as a teacher in a High School during a gap in my career, the time that I didn't have any other job..., when I came back to Greece from the UK (I had just completed my PhD there), while I was pregnant... till we founnd out what we finally would do, Education was a very good choice... considering that I worked there only for a short time, 2-3 years, it was a very interesting experience".

However, it seems that a career in Academia is a preferable vocational choice for Bioscientists, especially for those who hold lots of educational qualifications:

"When I first came back (to Greece) I believed that I would find a position in a university, but there weren't any at that time. Maybe if I had tried harder, I could have found something". 


\section{Macrothink}

International Journal of Human Resource Studies

ISSN 2162-3058

2016, Vol. 6, No. 3

"I believed that in my career, there were two crossroads since I had completed my first degree in Biology: the first option was to continue my studies in order to have an academic career and the other one was to work in the pharmaceutical industry. To be honest I didn't chase the first one so much and I took the risk to follow the pharmacy sector, thinking that this would be a better choice".

But they underline that there are some difficulties finding an academic position:

“...And I came back to Greece and I started looking for a job... I assumed that I would continue my career in the university, since I was an academic there (in the UK). I sought a position in many universities but I couldn't find something specific. I had studied a lot, I held a PhD, I had a previous job experience on that field and to be honest, I was really disappointed that period".

"The problem with the academic career is that many people hold PhDs in Biology but the positions are really few”.

"It is sometimes a matter of luck or circumstances. That time we came back to Greece it was a very special period, because 3 new Bioscientists' Departments were established in the Greek universities at the same time,... we had a boom of academic positions out of a sudden... Thus, we managed to start working in Academia”.

Some of the answers reveal a disappointment -even a bitterness- concerning the academic career:

"University is a very promising and interesting workplace. It is ideal, you work with young people, you can have your research, but working in a Greek university means you are dealing with its pathogeneses as well... you could never enter Academia, unless you have some strong connections to some 'powerful' professors who would then support you, or you if you are the son of a professor -no matter if you are capable or not. I had none of these 'criteria'..."

"...some months after I started looking for an academic position I estimated the situation and how it all worked,... I was deeply disappointed..."

“...I returned and worked as a external university teacher for 2 years. In 2006 I quit Academia because I couldn't see anything more there; I understood that I couldn't follow an academic career".

Also, it is pointed out the lack of pedagogical training for academics, along with some suggestions:

"In Academia you need a pedagogical background that we do not have... We learn on the job, through our experience. Some seminars should be held for the academics in order to learn how to teach people aged 18-25... and there are some universities abroad that offer this kind of seminars and lessons to their new academics". 


\section{Discussion}

Bioscientists in Greece, like all young graduate scientists, through a developmental process as has been indicated by Kantas \& Chatzi (1991), seem to succeed in making the best possible career choice, matching their studies, knowledge and abilities on the one hand and the demands of the world of work on the other. Therefore, the main points of Super's (1984) career developmental theory are confirmed, since their career path is determined not only by personal characteristics (e.g. interests, gender, values, personality) but also by the current economic situation and opportunities offered at the time of their career choice.

According to our study some key issues about the career of Bioscientists are aroused. Career choice is a personal matter which takes place within the Bioscientist's career development, taking into account realistic difficulties in employment, which have been aroused especially during the recent years of the economic crisis. The workplace of Biosciences includes peculiarities, difficulties but offers a lot of alternatives as well, all of them however, don't form an easy work path in Greece. Therefore, since employment of Bioscientists seems difficult, Education is a safe work perspective for them, especially in Greece.

The results show that the concerns of Bioscientists about their career mean that they have crossed all the stages of their professional development, as they have been described by Ginzberg et al., (1951), stabilizing their work preferences at the realistic stage, where the choice of their job field is accomplished through the phases of a) investigation, b) crystallization and finally, c) determination of occupation. Sometimes, they tend to decide for the "easiest" option, that is working in Secondary Education, but they do not hesitate to search other careers in different areas, where a Bioscientist can be absorbed.

Bioscientists who have chosen to work as high school teachers in public Education, built their choice on the attractiveness and benefits of the teacher's profession (Kedraka, 2013), along with the desired balance between professional and family life (Feibelman, 1993), that Education offers (e.g. long holidays, fewer working hours per week, decent salary). Therefore, Bioscientists, working as teachers, seem to be motivated from realism, taking into account the difficult employment regarding Biosciences, a key-point in career decision, as Ginzberg et al. (1951) noted. The results of this study confirm that working in Academia is considered an ideal career option, because it offers to the Bioscientists a -relatively- permanent job and allows them to continue with their research as well, since many of them hold a $\mathrm{PhD}$ (Robbind-Roth, 2006). However, finding a position in Academia is neither simple nor easy (Longman, 2006), especially in Greece, where the academic positions are hard to find, based always on numerically limited job offers in this field.

Concerning Bioscientists who haven't chosen Education for their career, it seems that employment standards, chances and expectations affected them in order to chase a more competitive career in the private sector. Probably, they were more likely to chase more demanding positions because those with more educational qualifications are less probable to see themselves as school teachers. It is also possible that these interviewees have higher self-efficacy level, since the higher the self -esteem is, the greater the range of vocational prospects they pursue, as Bandura argues (1977, 1995). In addition, we can have a better 
understanding of the vocational choices of Bioscientists considering the theory of Expectancy Value by Eccles $(1983,2009)$, according to which, when people consider their goal important and interesting, they try harder and give it more time. Thus, the expectation of success and the value that individuals put on different professions, directly affects their future ambitions concerning their career. However, it has been noticed that some Bioscientists have started their career making an initial choice as teachers - mostly in universities- and later they followed different work paths due to more mature decisions. As Ginzberg (1972) argues, despite the importance of our decisions on the first years of maturity, making new, more efficient vocational decisions is a lifelong process since we seek for a better combination of reality and personal pursuits.

\section{Conclusions}

The current study argue that for Bioscientists in Greece job seeking leads to different professional roles -especially in the middle of the current crisis, economical and social at the same time, but they are conscious of their concerns on job finding. For them, professional development is a lifelong process of evolution and self-perception gaining: it is a synthesis between personal and socioeconomic factors, between self-perception and reality, as Super argues in his developmental theory. Taking into account the actual economic, social, working and personal conditions at the time of work decision, including the need for survival and the dream of a decent living, a career in Education often becomes a "good" choice, considering the difficulties in finding a job in the field of Biosciences. However, other Bioscientists have chosen to work in other than Education areas, drawn by their ambitions and qualifications. In any case, Bioscientists seem to make their occupational choices according to their values and their interests, taking into account the current economic and social circumstances and their own learning experiences, but still following their heart within a realistic pattern.

\subsection{Limitations of the Research}

We note that the research interest of the current study focused on the in-depth highlighting of views and experiences of Bioscientists, so we would better understand their career choices and development. It is stressed out that this is a small scale study and the qualitative analysis is based on a very small sample of the total population among Bioscientists in Greece. Therefore, it is indicative and no generalization of these conclusions is implied.

\subsection{Suggestions for future Research}

The current study is a qualitative research, leaving a lot of issues open for further investigation. Reflecting of the concerns aroused in this study, we propose that future research would be interesting to focus on work engagement within the working organization, work values and job satisfaction, as well as possible conflict between work and family life for Bioscientists, since data regarding such issues is rare. 


\section{Macrothink}

International Journal of Human Resource Studies ISSN 2162-3058 2016, Vol. 6, No. 3

\section{References}

Ambrose, S.G. (2006). Science writing: Communicating with the masses. In: Cynthia Robbins-Roth, (Ed). (2006). ALTERNATIVE CAREERS IN SCIENCE. Leaving the Ivory Tower,27-38. ELSEVIER Academic Press Inc.

Bandura, A. (1977). Social learning theory. Englewood Cliffs, N. J.: Prentice-Hall.

Bandura, A. (1995). Self-efficacy theory, the exercise of control. N.Y.: W. H. Freeman \& Company.

Belikoff, K. (2004). Opportunities in Biological Sciences Careers. N.Y.: McGraw-Hill Companies, Inc.

Bloomfield, A.V., \& El-Fakahany, E. E. (2008). The Chicago Guide to your Career in Science. Chicago: The University of Chicago Press.

Brown, S.Sh. (2007). Opportunities in Biotechnology Careers. New York: McGraw-Hill Companies, Inc.

Camenson, B. (2003). Great Jobs for Biology Majors. NY:McGraw-Hill Companies, Inc.

Eccles, J.S. (1983). Expectancies, values and academic behaviors. In J. T. Spence (Ed.), Achievement and achievement motivation,75-146. San Fransisco, CA: Freeman.

Eccles, J.S. (2009). Who am I and what am I going to do with my life? personal and collective identities as motivators of action. Educational Psychologist, 44, 78-89.

Feibelman, J.P. (1993). A Ph.D. Is Not Enough! Guide to Survival in Science. NY: Basic Books

Ginzberg, E. (1972). Toward a theory of occupational choice, A restatement. Vocational Guidance Quarterly, 20, 169-176.

Ginzberg, E., Ginsburg, S.W., Axelrad, S., \& Herma, J.L. (1951). Occupational choice: An approach to a general theory. New York: Columbia University Press.

Horizontal Support Action of the Universities' Career Offices. (2008). GREEK UNIVERSITY GRADUATES IN THE LABOUR MARKET. Nationwide survey on graduates of the years 1998-2000. (edit.: Prof M. Karamesini). Athens: Dionikos (in Greek).

Kantas, A., \& Chatzi, A. (1991). Psychology of work. Theories of professional development. Counseling elements. Athens: Elinika Grammata (in Greek).

Kedraka, K. (2008). Methodology of taking an interview. Available in the webpage of the Hellenic Adult Education Association (HAEA): www.adulteduc.gr (in Greek).

Kedraka, K. (2013). Education as a work prospect for Bioscientists in Greece. Nea Paideia, 148, 88-112 (in Greek).

Krumboltz, J.D. (1979). A social learning theory of career decision making. In: A. M. Mitchell, G. B. Jones, J. D. Krumboltz. (Eds). Social Learning and career decision making. 


\section{Macrothink \\ International Journal of Human Resource Studies \\ ISSN 2162-3058 2016, Vol. 6, No. 3}

Cranston, Rhode Island: Caroll Press.

Kyriazi, N. (1998). The sociological research - Critical review of methods and techniques. Athens: Greek Scientific Publications (in Greek).

Longman, R. (2006). Creating a Publishing Empire: How I Gave Up Academia and Became an Entrepreneurial Editor. In: C. Robbins-Roth (Ed). (2006). ALTERNATIVE CAREERS IN SCIENCE, 39-46. Leaving the Ivory Tower. ELSEVIER Academic Press Inc.

Robbins-Roth, C. (Ed). (2006). ALTERNATIVE CAREERS IN SCIENCE. Leaving the Ivory Tower. ELSEVIER Academic Press Inc.

Roth, R. (2006). Entering Biomedical and Scientific Consulting. In: C. Robbins-Roth, (Ed). (2006). ALTERNATIVE CAREERS IN SCIENCE. Leaving the Ivory Tower, 149-160. ELSEVIER Academic Press Inc.

Super, D.E. (1984). Career and life development. In D. Brown, L. Brooks et al. (Eds). Career choice and development. San Francisco: Jossey-Bass.

Verma, G., \& Mallick, K. (2004). Educational Research. (D. Papastamatis Ed., E. Griva transl). Athens: Typothito (in Greek).

\section{Copyright Disclaimer}

Copyright for this article is retained by the author(s), with first publication rights granted to the journal.

This is an open-access article distributed under the terms and conditions of the Creative Commons Attribution license (http://creativecommons.org/licenses/by/3.0/). 